\title{
BOEKAANKONDIGING.
}

Mr. T. M. C. Agser, Hoogleeraar en Adrokaat to Amsterdam. Schets van het Nederlandsche Handelsregt, ook ten dienste van het Middelbnar Onderwijs. Haarlem, de ERVEN F. BoHN, 1872.

Nog steeds komt onder de vakken, die op de hoogere burgerscholen met vijfjarigen cursus volgens de wet onderwezen moeten worden bet "handelsrent" voor. Handelsregt, dat is niet alleen het Nederlandsch burgerlijk handelsregt, maar volgens het Besluit van 2 Febr. 1864 (Slaatsbl. $\mathbf{n}_{0} .8$ ) "het handelsregt in zijne "hoofdtrekken, in het bijzonder het Nederlandsche Handelsregt zoo"als het in het Wetboek van Koophandel en in de afzouderlijke wetten "beschreven is. Hiertoe behooren ook de Nederlandsche tariefwetten „en de scheepvaartwetten." Derbalve niet alleen Nederlandsch maar ook algemeen, niet alleen burgerijk - maar ook publiek-regtelijk handelsregt. Voorwaar een uitgebreid vak en moeijelijk, vooral voor jongelingen, die van bet regt in het algemeen niets kunnen weten, die de eenvoudigste begrippen van publiek en privaat regt vreemd zijn. Ik voor mij heb steeds getwijfeld aan de mogelijkheid of het onderwijs in dat vak op die plats gegeven eenige de moeite beloonende resultaten kan geven, en zoude wenschen, dat onze jongelingen van wie reeds zooveel gevergd wordt, ten minste van dit vak bevrijd werden. Mogten zij zich aan den handel wijden, dan voorzeker zal het hun nuttig zijn, indien de voornaamste onderwerpen van handelsregt hun niet vreemd zijn, maar dan bestaat er voor hen ook de gelegenheid om dit op de handels school te leeren.

Intusschen de wet beveelt dit onderwijs en verscheidene regtsgeleerden hebben pogingen aangewend, om de moejjelijke taak van de onderwijzers in dit vak te verligten door het schrijven van populaire boeken over handelsregt. Ik noem maar alleen Mr. J. VAN Giar, die in 1864, eene zeef verdienstelijke handleiding tot 
de beoefening van het Nederlandsche handelsregt in het licht gaf, waarvan ik de eer had een verslag te geven in den Ned. Spectator $1864 n_{0} 45$, en $n u$ onlangs de practische en theoretische beoefenar van ons handelsregt Mr. T. M. C. Asser, Hoogleeraar en advocaat te dmsterdam, van wiens werk ik op uitnoodiging der redactie van dit Tijdschrift gaarne een verslag wil geven.

Het handelsregt hier door Mr. Asser bedoeld, is alleen het burgerlijk handelsregt, niet het publiekregtelijke en wel voornamelijk die onderwerpen van handelsregt, die in het Wetboek van Koopbandel behandeld worden. Hij behandelt dus volstrekt geen onderwerpen van algemeen burgerlijk regt, ofschoon dit, zoowel voor bandels- als voor gewone burgerlijke zaken, de beginselen aangeeft waarvan de bijzondere handelsregterlijke regelen slechts wijzigingen of toepassingen zijn.

Bij ieder van de door hem behaalde onderwerpen bepaalt hij zich tot eene zoo duidelijk mogelijke verklaring van de hoofdbegrippen zonder zich met de juridische redeneringen, noch in de uiteenzetting der bijzondere wetsbepalingen te verdiepen. Zijn hoofddoel is dan ook eene verduidelijking der hoofdbegrippen, die voor den niet jurist onmisbaar is, om hem in staat te stellen met vrucht het. Wetboek van Koophandel te raadplegen.

Ik geloof, dat hij dit doel voor een groot gedeelte bereikt heeft. Ik meen, dat hij de begrippen van de roornaamste in het Wetboek van Koophandel behandelde onderwerpen duidelijk en juist heeft voorgesteld en daardoor voor den beginnenden beoefenaar van ons Wetboek van Koophandel do taak zeer verligt heeft.

S. verdeelt zijn werk in drie afdeelingen. In de eerste afdeeling handelt hij over den kroophandel in 't algemeen, in de tweede over de scheepvaart en het vervoer te lande, en in de derde over verzekering en bodemerij.

De eerste afdeeling is verdeeld in acht hoofdstukken; 10. bronnen van het handelsregt, wetboeken, gebruiken; 20, regtsmagt in handelszaken, regtspleging, arbitrage, bewijsvoering, koopmansboeken; 3o. omvang van het handelsregt, daden van koophandel, kooplieden; 40. vennootschappen; 5o. koop en verkoop, commissie, kassierderij; 6o. makelaars en beurzen; 70. de wissel en ander handelspapier en 80. faillissement, surséance en bankbreuk.

De tweede afdeeling telt rijf hoofdstukken; 10. schepen, scheepseigenaars, reederijen; 20. schippers en schepelingen; 3o. bevrachting van schepen, voerlieden, diligences, spoorwegen en expediteurs; 40. averij-grosse; 5o. aanzeiling, schipbreuk, stranden en zeevonden. 
De derde afdeeling bevat vier hoofdatukken: 10. verzekering in het algemeen; 20 . zee-verzekering; 30 . brandverzekering; landbouwverzekering, levensverzekering en 4o. bodomerij.

Men ziet het, de verdeeling is niet systematisch. Het faillisse ment wordt niet behandeld bij de regtsmagt in bandelszaken. Aan de overeenkomst en verzekering wordt een afzonderlijke afdeeling gewijd, terwijl de wissel en ander handelspapier, alsof zij gewone overeenkomsten behelsden, met de andere handels overeenkomsten tegelijk behandeld worden. Het doel ran den schrijver was dan ook niet om een kort systeem van handelsregt te geven, maar alleen om de boofdbegrippen duidelijk uit een te zetten en dat heeft hij gedaan.

Het spreekt wel van zelf, dat niet ieder dier uiteenzettingen mij even juist voorkomt. Indien ik moest kiezen, dan zoude ik aan de uiteenzetting der verzekeringen de voorkeur geven, want dit moeijelijke onderwerp is door den $S$. eenroudig en juist, kort en helder uiteengezet. Ik zoude daarentegen de uiteenzetting van den wissel minder kunnen goedkeuren. Daar wordt te veel gehecht aan de theorie van Pothier, die in den Code de Commerce was opgenomen en ook nog in de ontwerpen van ons Wetboek werd gevolgd, doch die niet de grondslag is van de practische bepalingen van óns Wetboek. Wel zijn sommige meer theoretische artikelen zooals art. 100 en 140 op die theorie gegrond; de ontworpen bepalingen echter, die meer direct van praktischen aard waren, hoezeer dan ook de noodzakelijke gevolgen van de theorie, (zooals de voorgestelde bepaling, dat de acceptant ongehouden is, indien de handteekening des trekkers valsch is, of dat wisselbrieven behelzende verdichte opgaven allen kracht hebben als gewone schuldbekentenis zelfs ten aanzien van derden, of zelfs de bepaling, dat de wisselverbindtenis gegrond was op een overeenkomst van koop en verkoop), werden door de Kamer niet aangenomen, tengevolge van bet verzet van handel en praktijk, verpersoonlijkt in de heeren Hooft en Donker Curtius.

Ons positief wisselregt steunt dus niet meer op de theorie van Pothier. Men heeft die theorie verworpen zonder zich echter voor eene andere te verklaren. Men heeft de theorie overgelaten aan de school en zich bepaalt tot de aanwijzing van de uitwerkselen der wisselteekening. $\left(^{*}\right)$ Die uitwerkselen zal men voor den

(") Zie redevoering van den heer Donker Curtius bij Voorduin I bl. 519 on opinions enoncées bl. 44. 
aanstaanden boopman beter verklaren, uitgaande van het beginsel dat de verbindtenis ontstaat uit het schrift, volgens het oude adagium van Baldus (*). "wat ik geschreven beb, dat beb ik geschreven", dan steunende op de theorie van het wisselcontract die alleen ontstaan is door verwarring van de eigenlijke wisselverbindtenis met de voorafgaande overeenkumsten van partijen.

Ook omtrent de voor den bandel zoo belangrijke cognoscementen en ceelen is de $\mathrm{S}$. niet bepaald genoeg en meent hij dat het juridisch karakter van het cognoscement nog steeds zoo onzeker is, dat levering door cognoscementen niet zonder gevaar kan geschieden. Ik geloof wel, dat die uitspraak den jeugdigen handelaar zal verbazen, die dagelijks belangrijke hoeveelheden koopwaren op cognoscementen en ceelen ziet verkoopen. Wij zijn dan wel achteruitgegaan sinds de dagen van den adrocaat A. v. d. Ende, die in $1706(\dagger)$ verklaarde, "dat het in rechten en practicque resolut "en zeker is, dat door middel van een lasthebber, facteur of "commissionair de possessio en door de possessio ook de eigendom "der lasthebbers wordt gerequireerd."

De talentvolle $\mathrm{S}$. houde mij deze opmerkingen ten goede. Ik wensch zijn in een aangenamen stijl geschreven boek in veler handen. Geen beoefenaar van het handelsregt zal het zonder vrucht lezen en herlezen. J. G. KIST.

(") Zie Holtius, Wisselregt der XIV eeuw bl. 21.

(†) Zie Barels, Adv. II bl. 84. 
OPGAVE van de hoogste en laagste Coursen van de onderstaande Effecten aan de beurs te Amsterdam.

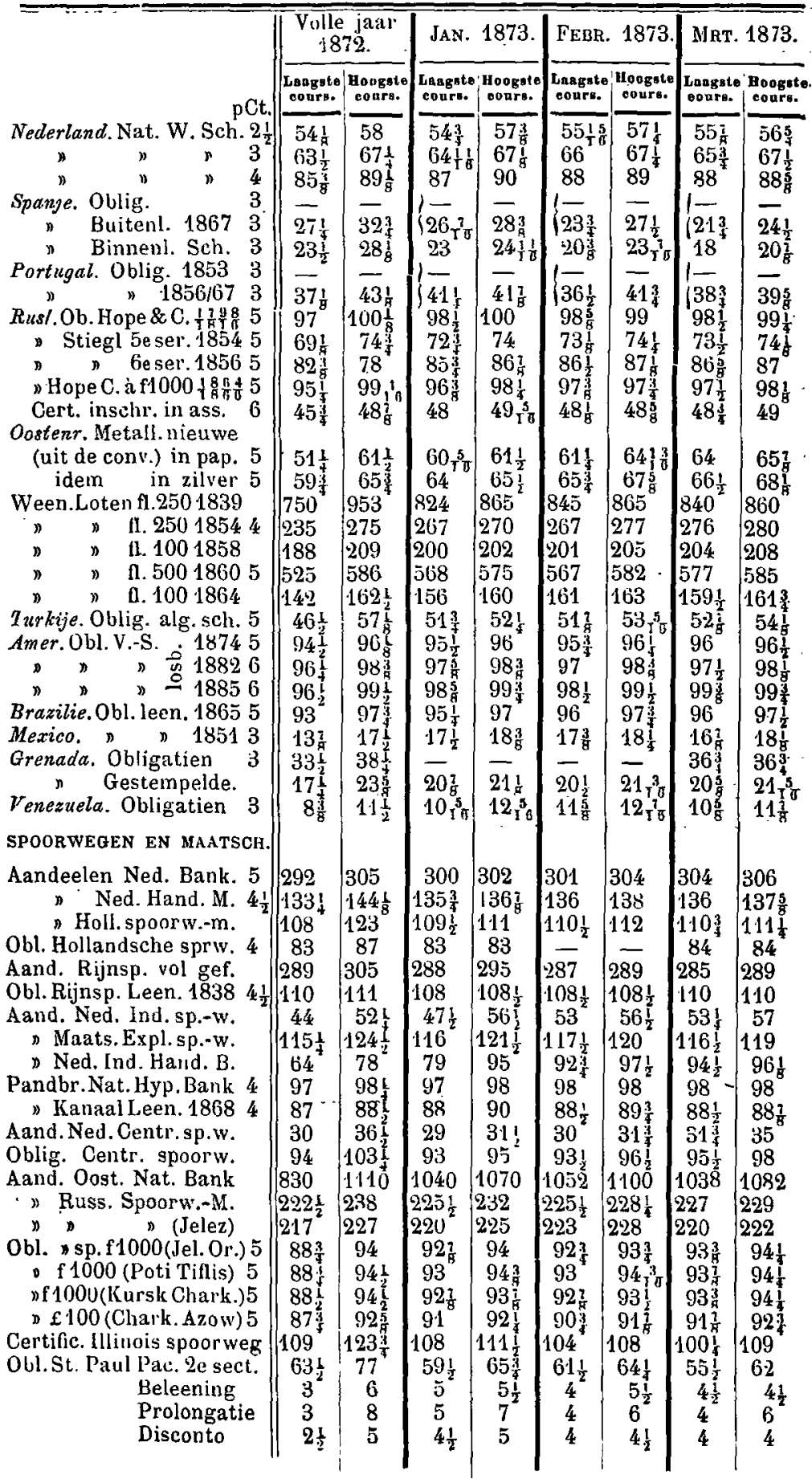


Nederlandsche Bank. (In millioentallen guldens.)

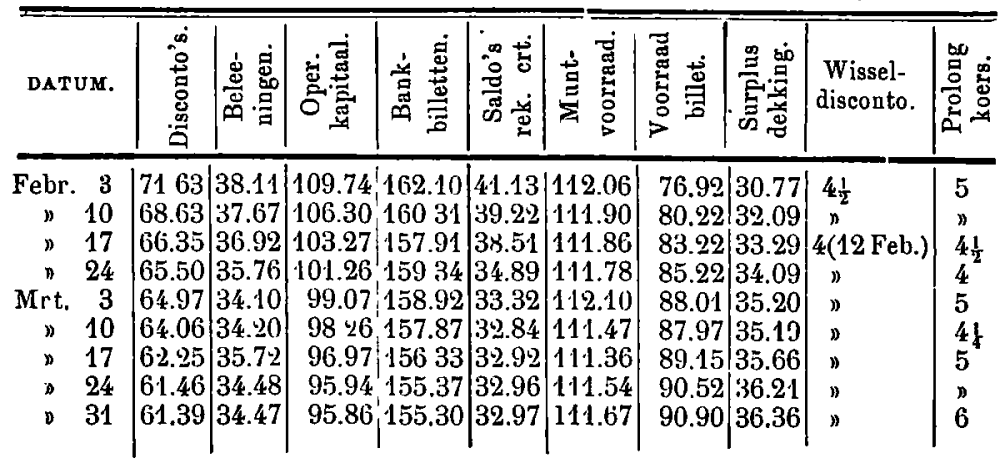

Wisselkoersen te Amsterdam.

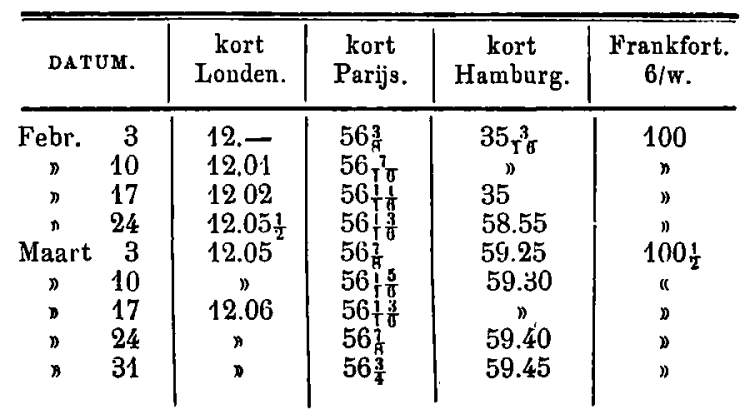




\section{ONZE SCHEEPVAARTBEWEGING.}

De M a asteden. - MAART 1873.

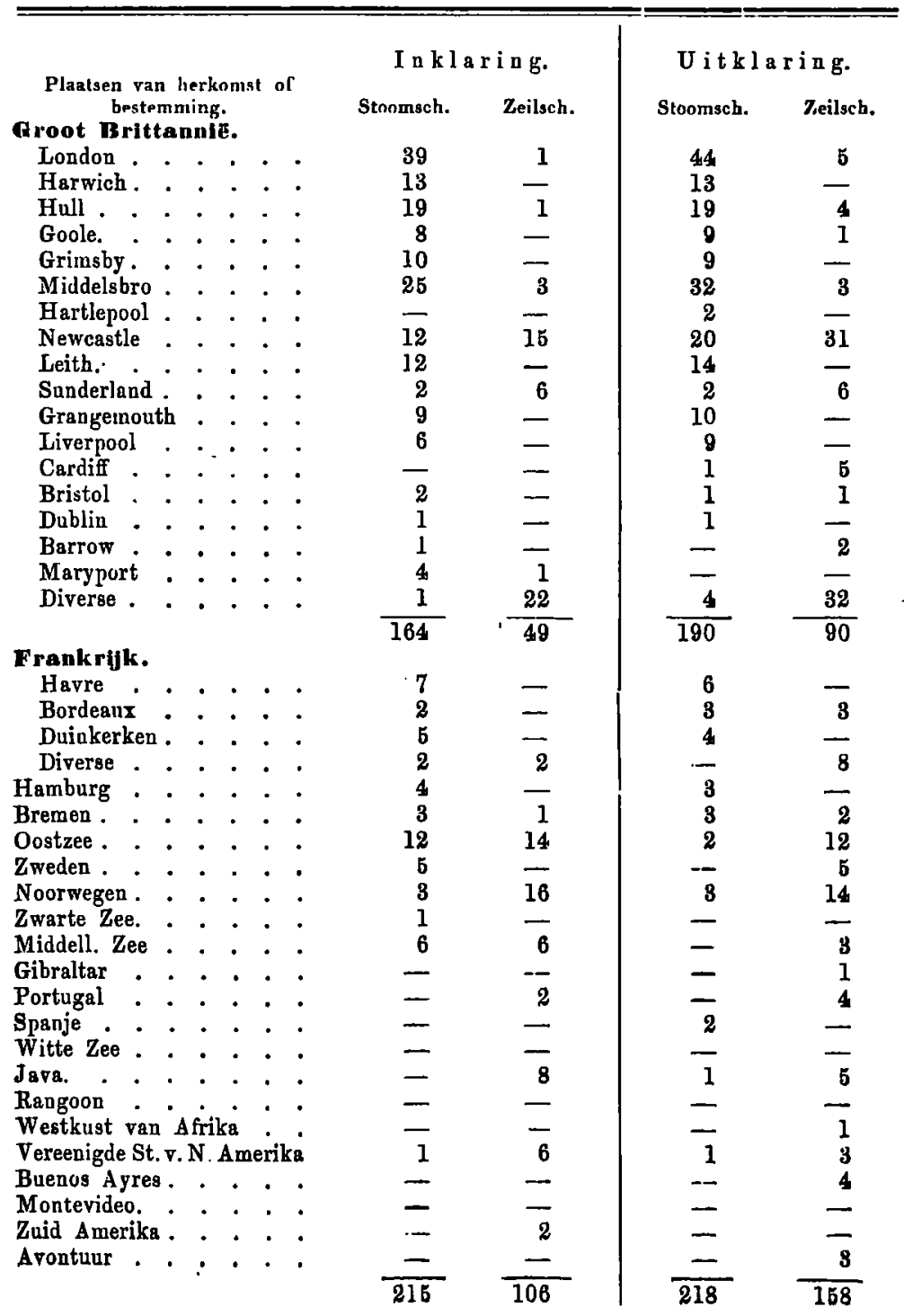


I n k laring.

Stoomsch. 7rilsch.

Hellevutsluig $\quad 139 \quad 72$

Brielle

Brouwershaven

Hoek van Holland 5

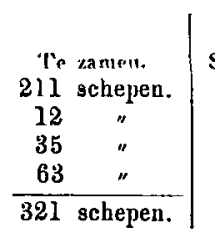

\begin{tabular}{|c|c|c|c|}
\hline \multicolumn{4}{|c|}{ U itklaring. } \\
\hline $\begin{array}{c}\text { Stcomsch. } \\
64\end{array}$ & $\begin{array}{l}\text { Zeilschi. } \\
52\end{array}$ & $\begin{array}{l}T 16 \\
116\end{array}$ & $\begin{array}{l}\text { zamrn. } \\
\text { schepeu. }\end{array}$ \\
\hline i & $l$ & 3 & 4 \\
\hline 4 & 7 & 11 & " \\
\hline 148 & 98 & 248 & N \\
\hline 218 & 58 & 376 & hepen \\
\hline
\end{tabular}

Texel. - MAART 1873.

\begin{tabular}{|c|c|c|c|c|c|c|c|c|}
\hline \multirow{2}{*}{\multicolumn{5}{|c|}{$\begin{array}{l}\text { Plaatsell van herkomst of } \\
\text { hestrmming. }\end{array}$}} & \multicolumn{2}{|c|}{ Inklaring. } & \multicolumn{2}{|c|}{ Uitklaring. } \\
\hline & & & & & Stnomsch. & Zeilsch. & Stoomsch. & Zeilsch. \\
\hline Ĺondon. & . . & . & . . & & 6 & 4 & 6 & 4 \\
\hline Hull. . &. & . . & . . & & 7 & - & 6 & - \\
\hline Goole & . & . & . . & & 1 & 一 & 1 & $\ldots$ \\
\hline Middelsbro & . . &. & . . & . & 一 & - & - & 1 \\
\hline Liverpool & . . &. & . . & •. & $\ldots$ & - & - & $=-$ \\
\hline Newcastle &. &. &.$\quad$. & . & $\mathbf{3}$ & 3 & 4 & 19 \\
\hline Sunderland & . . & . . & . . & •. & 5 & 3 & 4 & 3 \\
\hline \multirow[t]{2}{*}{ Diverse . } & . . & . $\cdot$ & . . & - & - & 7 & -- & 10 \\
\hline & & & & & 22 & 17 & 21 & $37-$ \\
\hline \multicolumn{5}{|l|}{ Frankrijk. } & & & & \\
\hline Bordeaux. & . & - & - & • & $\boldsymbol{2}$ & - & 3 & 1 \\
\hline Nantes. & . &. & . & • & - & - & - & - \\
\hline Diverse . & . . & $\cdot \cdot$ & - . & - & 1 & 2 & - & 1 \\
\hline Hamburg . & . . & • & . & . & 3 & - & 4 & 2 \\
\hline Oostzee. &.$\quad$. & .. & . . & . & 2 & 13 & 2 & 13 \\
\hline Zweden. & . . &.$\quad$. & . . . & . & - & - & 1 & - \\
\hline Noorwegen. & . &. & . . & • & 2 & 29 & 1 & 24 \\
\hline Zwarte zee. & . . &. & . . & . & - & - & - & - \\
\hline Middell. zee & - & . & . . & , & 3 & - & 3 & 4 \\
\hline Javia. . &. &. &. & . & - & 12 & 1 & $\underline{9}$ \\
\hline Vereen. Stat. & v. $\mathrm{N}$ & ง. Ame & rike & & - & 2 & - & $\overline{\bar{E}}$ \\
\hline Wést Indië. &. & . . & . . & . & - & 1 & - & $\mathbf{3}$ \\
\hline Montevideo. & . . &. & . . & . & - & - & - & 2 \\
\hline Brazilie . & . &. & . . & . & - & - & - & - \\
\hline Peru. . & . & . . & . . & . & - & - & - & - \\
\hline Calcutta. & . & . . & . & . & - & - & - & - \\
\hline Arontuur. & . &. &. & . & - & - & - & 2 \\
\hline \multirow[t]{2}{*}{ Buenos Ayres } & &. & . & . & - & $\boldsymbol{Z}$ & - & 2 \\
\hline & & & & & 35 & 78 & 36 & $\overline{105}$ \\
\hline
\end{tabular}




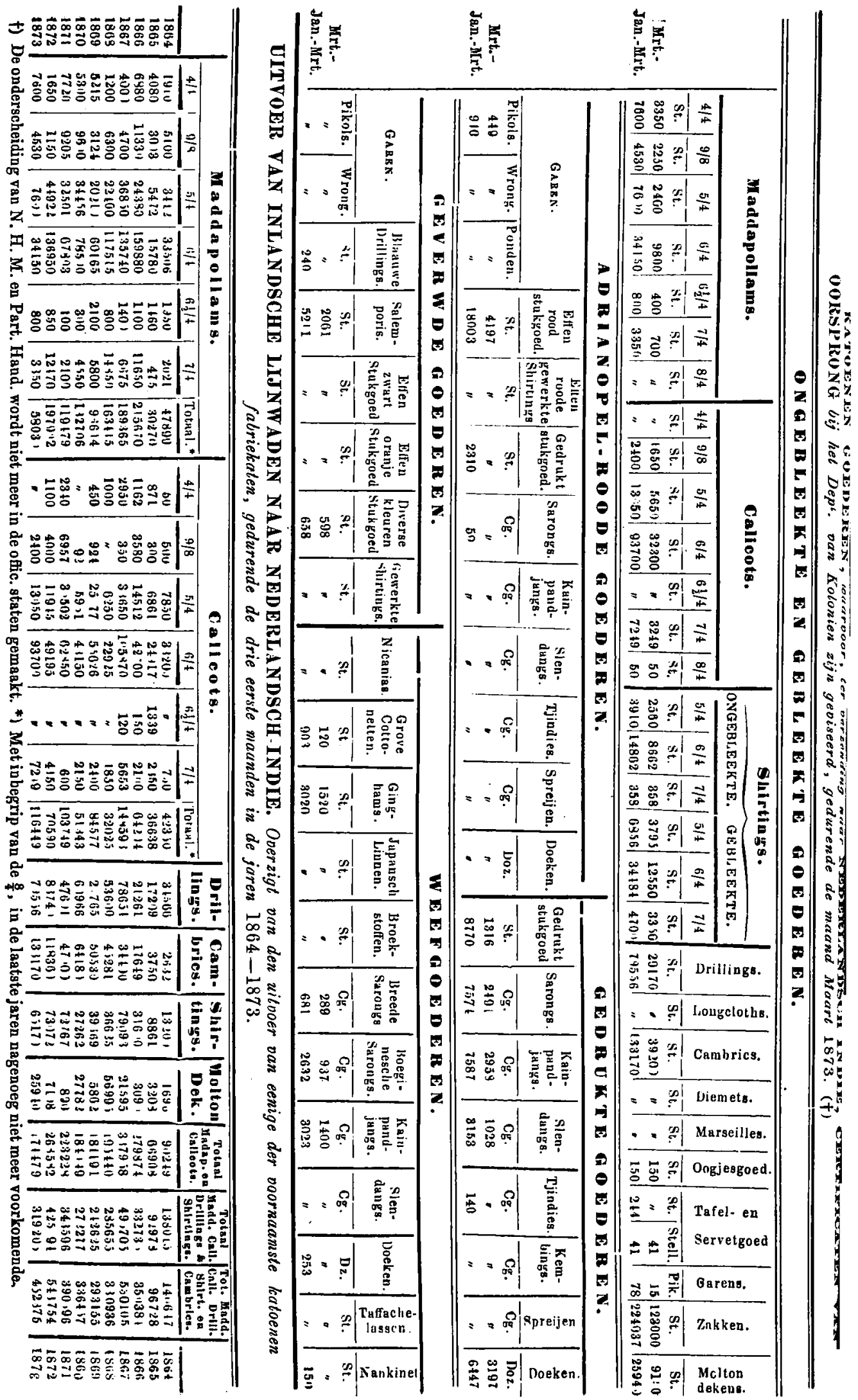




\section{ECONOMISCHE NALEZINGEN EN BERIGTEN.}

Verbeterde aardappelteelt. Een jaar of vier geleden is er in Duitschland over dit onderwerp een boekje van Gülich in het licht verschenen, dat nog al opgang gemaakt heeft en, voorleden jaar in bet Nederlandsch vertaald, misschien menigeen ook hier te lande zal aansporen om het voorschrift van den Duitscher na te volgen. Wij, die gewoonlijk nog al zorg voor onze aardappels over bebben en meestal best weten wat een goed telen vereischt, vinden niet bijzonder veel nieuws in dit boekje. Velen zullen zeer zeker in hun tuin wel eens eenige nitgelezen aardappels juist op die wijze behandeld en verbazend groote opbrengsten van een' enkelen struik verkregen hebben. Gülich raadt namelijk aan, om aan elken pootaardappel bijna een vierkante meter, 0,98 $\mathrm{m}^{2}$, ruimte te geven, en om het midden den mest ringrormig te spreiden en onder te spitten. De poter, zoo groot mogelijk genomen, wordt dan op het midden gelegd, zoodat hij geen mest raakt, met het kiemeinde naar boven, en dan met 5 centimeter aarde bedekt. Na het opgaan behoort men te schoffelen en te hakken over dwars en over lang, en dan aan te hoogen en een paar maal aarde op den struik te leggen, zoodat het loof zijdelings uiteengespreid geraakt. De aardappel komt alzoo niet dieper dan de oppervlakte van den akker, door mest omringd, in een heuveltje te liggen, en vormt zonder twijfel groote en vele aardappels; maar, gelijk nadere proeven geleerd hebben, niet zooveel meer, dat zulks opweegt tegen de groote ruimte welke elke der pollen op zich zelven inneemt. Alvorens wij de aardappelziekte kenden, die jaarlijks het vroeger zoo verbazende uitstoelen komt beletten, was een dergelijk poten misschien raadzaam, thans is het zaak om ons te houden aan de tegenwoordige gebruikelijke wijze, zonder in den herfst te mesten, op rijen telen, aanaarden en geheel zuiverhouden van onkruid, te verznimen.

De nadere proeven met het Gülichscbe aardappelpoten zijn op een veld, zeven hectaren groot, genomen, door den beroenden directeur der landbouwschool te Halle, Dr. Julius Kühn. De ruime schaal waarop de proef genomen is, waarborgt ons, dat zij afdoende is. Het veld werd in zeven akkers afgedeeld, die men elk op vier verschillende wijzen, met elf soorten van aardappelen, door Gülich zelven geleverd, bepootte.

Vooreerst a) de Gülichsche wijze van poten met bijna een vierkante meter ruinte voor elke plant; 6) de rijen 0,6 meter, de planten $0,4 \mathrm{~m}$. 
uiteen en de poters $0,1 \mathrm{~m}$. diep gelegd; c) de rijen $0,45 \mathrm{~m}$., de planten $0,4 \mathrm{~m}$. uiteen en de poters $0,15 \mathrm{~m}$. diep; en $d$ ) de rijen, eveneens 0,45 en de planten $0,4 \mathrm{~m}$. uiteen, maar de poters als bij b) $0,1 \mathrm{~m}$. diep. $b$ ), c) en $d$ ) bragten allen vrij wat meer op dan $u$ ); $d$ ) in de meeste gevallen een derde tot de helft; $c$ ) was blijkbaar te diep gepoot en gaf slechts eén. wëinigje meer dan a). De 1ste akker was met 2400 Kg. schapenmest op de $\mathrm{Ha}$ bemest, in den herfst ondergeploegd; de 2de met even zooveel schapenmest in 't voorjaar ondergeploegd; de 3de met $3200 \mathrm{Kg}$. schapenmest in den herfst en even zooveel in de lënte gếploêgd; de 4de 'met $3200 \mathrm{Kg}$. schapenmest alleen in d'e lente geploegd; de 5 le beimest mèt $400 \mathrm{Kg}$. superphosphaat van Bakerguàno, $200 \mathrm{Kg}$. opgelóste Peruguano en $200 \mathrm{Kg}$. op de hectare Kàlimagnesih, met hérfst en Iente ploegeñ; de 6de met 60 Ha stadsbeer op de hectare, in den berfst 'géploegd en de $7 \mathrm{de}$ met even zoeveel beer, doch in het voorjaar geploeǵd. De eerste akker, met schapenmest en in den herfst geploegd, gaf het meest, daarna de tweede en vervolgens de zésdé en zevende.

Wanneer eene proef op zulk eene groote schaal en met zooveel zórg genomen wordt; is zij zonder het minste bedenken afdoende, en men mag Dr. Julius Kühn van harte danken dat hij aan het dweepen met Gülich's voorschrift voor goed een einde gemaakt heeft. (Volksol.)

- Brood- en meelfabriek te 's Gra venhage. Den $9_{n}$ April is onder vóorzitterschap van Mr. P. P. van Bosse, de jaarlijksche algemeene vergadering van aandeelhouders in deze naamlooze vennootschap gehouden. Uit het doör den voorzitter medegedeelde verslag blijkt dat de gunstige toestand van het afgeloopen jaar vooral was toe te schrijven aan de oimstandigheid, dat de meelfabriek bet geheele jaar bijna zonder stoornis Heeft doorgewerkt. Het meel werd voornamelijk door de eigen bakkerij verbruikt en ook voor een deel aan anderen verkocht; ruim 350 last tarwe werd meer vermalen dan in het vorige jaar. Het debiet van alle soorten van brood bij elkander gerekend bedroeg $3,688,666 \frac{1}{2} \mathrm{~kg}$. tegen $3,729,669 \frac{1}{2} \mathrm{~kg}$. in $1871,3,571,357 \frac{1}{2} \mathrm{~kg}$. in 1870 en $3,281,334 \frac{3}{4} \mathrm{~kg}$. in 1869. De kleine vermindering, gerekend tegen 1871 , bestaat enkel in een tijdelijk minder debiet van bijzondere broodsoorten, daar de hoofdsoort, het gebuilde tarwebrood, op nieuw eene kleine vermeerdering ondervond. In verband tot de graan- en meelprijzen maar ook in vergelijking tot die in andere plaatsen, werden de broodprijzen matig gesteld, vooral wanneer men daarbij in aanmerking neemt dat bij de broodfabriek op den voorgrond wordt gesteld brood van zuivere le qualiteit en van goed gewigt. De balans over 1872 bedraagt in debet en credet $f 373,431.53$. Wederom kon een dividend van tien pCt. aan de deelhebbers uitgekeerd worden, terwijl darenboven nog een deel der winst werd gereserveerd tot dekking van een gedeelte der voorgenomen vitbreiding der meelfabriek. 
- Dat de ijzeren koe, zoo als de Engelschen de yuterpomp noemen, rijkelïk het hare bijdraagt tot het voorzien vah Melk aan de stede'lingen, weten wij ook in Nederland maar al te goed; en ook dat wasschen thet water en een beetje afroomen genoegzaam de eenige middelen zijn waardoor het vervalschen geschiedt. Melk-suiker uit Zwitserland aangevoerd, kalfhersenen, zooals men beweerde, en dergelijken behooren tot de zeldzame uitzonderingen. De gezondheids commissie van Mảnchester heeft alzoo een nuttig werk verrigt, door te bepalen hoe men uit bet roomgehalte en het soortelijk gewigt van de afgeroomde melk, besluiten kan tot den graad van vervalsching waartoe men geklommen is.

Room soortelijk gewigt van de
ten honderd.
afgeroomde melk.

Melk van slecht gévoederde koeijèn
Met water aangelengde melk ván goed gevoederde koeijen . . . . . . 6 , $6 \quad 7 \quad 1,02$ tòt 1,025

Met water aangelengde, gedeeltelijk afgeroomde melk van goed gevoederde koeijen. . . . . . . . . . . 2 . 2 , $3 \quad 1,02,1,015$

Gedeeltelijk afgeroomde, maar nièt met water vermengde melk . . . . 5 , 7 1,023 " 1,033

Goede onvervalschte melk $\quad 10 \quad 1,031$

Uitstekend goede melk $15 \quad 1,0335$

Hoe weinig men het gebruik van de ijzeren koe verbergt, blijkt ondèr anderen te Amsterdam, waar twee qualiteiten van melk verkocht worden, de eene voor algemeen gehruik bestemd, de andere voor zuigelingen en lieden, die gezondheidshalve melk drinken. Het verstandigste zou, dunkt mij; zijn, dat men altijd die dure melk, eerste qualiteit, gebruikte, om die dan naar eigen verkiezing veel of weinig te wasschen.

Te Dublin schijnt dat melkwasschen op eenen grootschen voet te worden gedreven. Door den regter werden, op het einde van het vorige jaar, veroordeeld: Maria Walsh, tot 160 gl. boete en 36 gl. kosten, wegens het verkoopen van melk met 80 ten honderd water aangelengd; Michael Gilligan, tot 14.4 gl. boete en $36 \mathrm{gl}$. kosten, wegens aanlengen met 60 ten honderd; James Grennau, tot hetzelfde, wegens hetzelfde aanleng'en: Christopher M'Robins, tot $96 \mathrm{gl}$. boete en $36 \mathrm{gl}$. kosten, wegens aanlengen met 30 ten honderd, en Morris Lynam, tot $60 \mathrm{gl}$. boete en 36 gl. kosten, wegens het aanlengen met 20 ten honderd water. De regter was overtuigd, dat deze boeten betaald werden uit een daarvoor bestaand fonds, en het speet hem alzoo zeer, dait hij niet bij magte was om ook tot gevangenisstraf te veroordeelen; maar hij had zich bevlijtigd om zulke boeten toe te passen dat de deelhebbers in het fonds die voelen zouden.

(Tolthsol.) 
- Dennenbossehen $\mathrm{Bij}$ het voortdurend toenemen onzer Dennenbosschen met het verdwijnen der heidevelden, zoo als met der tijd ook dat der kale zeeduinen, is het te voorzien dat men met het gebruik der deunen eenen anderen weg op zal gaan dan tegenwoordig. Misschien gaat het ons dan als in de Sologne in Frankrijk, waar men thans de opbrengst van een vijf-en-twintigjarig dennenbosch schat op let navolgende. De aankoop kost 100 gulden de hectare, het ploegen en hier en daar begreppelen 10 tot 15 gulden, het zaaizaad 4 tot 10 gulden, de eerste uilgaaf alzoo omstreeks 125 gulden de hectare.

Opbrengst op den leeftijd van: Opbrengst Kosten Zuivere

8 jaar, uitdunnen 3000 bossen

(bourrées) . . . . 45,- gl. 30,- gl. 15,- gl.

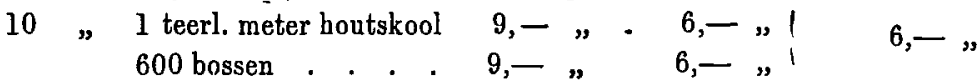

$12,3 \mathrm{~m}^{3}$ houtskool en 1000

bossen . . . . . . 33, — " 17,50, 15.50.,

15,200 bos schilhout (co-

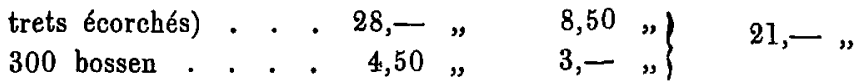

18 "400 bos schilhout en

500 bossen . . . . 67,50, 21, „ " 46,50,

25 , 1600 bos schilhont en

1600 bossen . . $\frac{264,-}{460,- \text { gl. }} \frac{80,- \text { " }}{172,- \text { gl. }}-\frac{184,-"}{288,- \text { gl. }}$

jaar]ijksche opbrengst alzoo . . . . 11,54,

of ten honderd . . . 9,23,

Rente op rente van het uitgeschoten kapitaal berekent men niet in le Sologne, want dan wordt de winst negatief. De som van 125 gl. tegen 4 pCt. rente op rente gerekend wordt toch $318 \mathrm{gl}$. (Volksvl.)

- Medailles voor werkbazen en werklieden. Het Nederoostenrijksch Gewerbeverein te Weenen heeft besloten, ter gelegenheid der Internationale Tentooustelling van 1873, eenige zijner medailles aan verdienstelijke werkbazen en werklieden, ook uit het buitenland, toe te kennen, zoo als dit genootschap zulks reeds sedert 1840 om de vijf jaren gedaan heeft voor zijne landgenooten, op aansporing van den verdienstelijken Weener industriëel Michael Spoerlin, die zijn voorstel met de volgende woorden inleidde: „Behalve de teclnische bekwaamheid is „er bij den arbeider nog een andere verdienste, die noch ter kennis „komt van het Nederoostenrijksch Gewerbeverein, noch tot die der 
„Regering, en daarom ook niet beloond kan worden; eene verdienste, „die binnen de werkplaatsen stil en zonder pronk bestaat, doch werkelijk „tot den gelukkigen gang van de industrieële onderneming bijdraagt: „die verdienste, welke trouwe en brave werkbazen door hun trouw en "gehechtheid verwerven. Zulke werkzame bazen, die met ijver en on„verdroten goeden wil hunne zware taak vervallen, die er steeds op "uit zijn om de zaak en de welvart van hun meester te doen gedijen, "die steeds de tusschenpersonen zijn tusschen den meester en zijne on„dergeschikten, deze industrieële officieren uit de bekwaamste en braafste „arbeiders als élite corps gekozen, deze hebben voorwaar in de eerste „plaats aanspraak op een algemeene waardering en belooning."

Het Gewerberein kent zijne medaille toe aan hen, die door langdurige, onberispelijk trouwe diensten, en ijverige bescherming van de belangen van den arbeidgever en energieke en toch humane behandeling der onder hen staande werklieden, en goeden levenswandel, en streven naar meerdere beschaving en een met goeden uitslag bekroond onderrigt van de hun toevertrouwde leerlingen daarop aanspraak kunnen maken. Aan buitenlandsche zal zij dit doen op voordragt nunner Commissiën.

Dientengevolge heeft de Nederlandsche Hoofdcommissie de Nederlandsche inzenders die zoodanige uitstekende werkbazen in hunne dienst mogten hebben, uitgenoodigd hunne namen met uitvoerige opgave hunner verdiensten op te geven aan den Voorzitter, den Stautsraad J. W. L. van Oordt, te Rotterdam, opdat de Nederlandsche Hoofdcommissie, na onderzoek, in staat worde gesteld een voordragt aan het Nederoostenrijksch Gewerbeverein te doen.

- Industrie in Noord-Amerika. Uit de aan het Congres medegedeelde bijzonderheden betreffende het in 1870 ingestelde tienjarig onderzoek naar den toestand der fabrieksnijverheid in de Vereenigde Staten blijkt, dat het getal fabrieken sedert 1860 (toen het 140,433 bedroeg) tot 252,148 is toegenomen; dat der werklieden in hetzelfde tijdvak van $1,311,24 \mathrm{C}$ tot $2,053,996$; dat van het in de fabrieksnijverheid gestoken kapitaal van $1,009,855,715$ tot $2,118,208,769$ dollars; de uitbetaalde loonen van $378,878,966$ tot $775,584,343$ dollars. De verwerkte grondstoffen beliepen in 1860 een kapitaal van 1,031,605,092 en in 1870 van 2,488,427,242 dollars, en de waarde der producten steeg van $1,885,861,676$ dollars in 1860 tot $4,232,325,442$ dollars in 1870 .

De fabrieksnijverheid is sedert 1850 het sterkste toegenomen in de staten van Nieuw Engeland en in de middenstaten; de grootste relative uitbreiding was echter op te merken in de jongste westelijke staten, Michigan, Wisconsin, Illinois, Missouri en Minnesota, waar de industrie in de laatste twintig jaren minstens vertiendubbeld is. In de zuidelijke 
staat was de vooruitgang tusschen 1850 en 1860 niet onbelangrijk, doch tusschẹn 1860 ęn 1870, ten gevolge van den burgeroorlog en de daaruit voortylopeijende desorganisạtie, betrekkelijk zeer gering. Alleen in Georgia ștẹeg de wagrarde der prodụctie yạn 1860 tot 1870 yan 16 tot 31 millioen dollars.

Nota der Redactie, pag. 256. Het artikel van den Hr. van Kerkwijk bevat meer dạ eene beschouwing, afwijkende van hetgęen wij als ons gevoelen omtrent belastingzaken, speciaal een income-tax, mededeelden. Onzes lezers wordt hierbij ten overvloede herinnerd, dat de Redactie door de plaatșing van geteekende stukken, niet wil geacht worden de verantwoordelijkheid voor den inhoud geheel op zich te nenın. RED. 